\title{
ANALYSIS OF PHYSICAL ACTIVITY STATES OF STUDENTS BETWEEN 7-16 AGE GROUP DURING COVID-19 PROCESS
}

\author{
Erkan Konca ${ }^{1 i}$, \\ Egemen Ermiş ${ }^{2}$ \\ Necati Alp Erilli ${ }^{3}$ \\ ${ }^{1}$ Yavuz Selim Secondary School, \\ Sivas, Turkey \\ ${ }^{2}$ Yaşar Doğu Faculty of Sport Sciences, \\ Department of Coaching Training, \\ Ondokuz Mayıs University, \\ Samsun, Turkey \\ ${ }^{3}$ Faculty of Economics, \\ Department of Econometrics, \\ Sivas Cumhuriyet University, \\ Sivas, Turkey
}

\begin{abstract}
:
Covid-19 virus, which entered our lives in the last period of 2019, has caused radical changes in our lives. After the pandemic was declared, the threat of the epidemic that affected the whole world caused us to change a large number of our habits. In particular, the periods when people were closed at home, which led to a decrease in physical activity levels. In our study, an international physical activity form was given to 278 students between the ages of 7 and 16. Physical activity levels of the students in the past week and what activities they did were found. 162 male students and 116 female students participated in the study. 28 of these students were in primary education, 154 were in secondary education and 96 were in high school. While 7 of the students who participated in the study had barriers to doing sports, it was found that 271 students did not have any. As a result of the analyses conducted about the prevalence of physical activity, it was found that the students were moderately active. It was found that $8.8 \%$ of the students were highly active, $23.8 \%$ were very active, $30.74 \%$ were moderately active, $19.11 \%$ were slightly active and $17.57 \%$ were inactive (sedentary). In terms of the ways of doing activity in general, it can be seen that during the pandemic, individuals preferred activities which were easy to do at home and on the street and also which were less risky. It can be said that sports branches performed as a team are generally avoided. Activities that are easy to do and less risky, such as running and walking for exercise, have come to the fore during the pandemic process.
\end{abstract}

${ }^{\mathrm{i}}$ Correspondence: email erkankonca@yahoo.com 
Keywords: physical activity, COVID-19, student

\section{Introduction}

The Covid-19 virus, which emerged towards the end of 2019 and which has affected the whole world since then, has threatened humanity seriously (Özdal, 2020). Coronavirus disease (COVID-19), which has been in our lives for a long time, is a viral disease that threatens our health, reduces our quality of life and causes us to change our habits in our daily lives. Studies conducted have shown that obesity is an important factor in the complications of this disease being more severe. In addition, the changes in eating habits and food shopping habits as a result of decreased physical activity and psychological factors such as fear and stress in long periods of staying home during the pandemic have increased the prevalence of obesity. Physical inactivity or sedentary life has been reported to be associated with anxiety, depression and cognitive dysfunction (Booth et al., 2012; Mayda et al., 2020). In the Covid-19 pandemic, elderly individuals and individuals with chronic diseases such as hypertension, diabetes, cardiovascular disease and chronic respiratory problems are more at risk (Pavón et al., 2020). In the study, which was conducted at the beginning of the pandemic process during home confinement, when BMI groups and physical activity levels of the participants were compared, statistical difference was found between groups' low physical activity and total physical activity $(18,9 \mathrm{~kg} / \mathrm{m} 2$ and $25-29,9 \mathrm{~kg} / \mathrm{m} 2)$ scores (Tural, 2020).

Covid-19 virus, which affected the whole world, has caused very big changes in individuals' lives. Pandemic has caused very serious sociological, psychological and physical problems. Problems such as the uncertainty about how the process will come to an end, problems such as the vaccine's being found but not being easily accessible have increased its negative effect on individuals. Many individuals who are active in their daily lives have begun to lead a sedentary life with the effects of pandemic. Different negativities were encountered while protecting from the Covid-19 virus. Changes in sedentary lifestyle and eating habits have caused an increase in the risk of obesity, which is one of the greatest problems of our day (Acar \& Yilmaz, 2021; Tural, 2020). All age groups have been affected of this situation negatively. It is a very high possibility for this effect to cause an increase in diseases such as cardiovascular diseases, obesity, diabetes, and anterior cruciate ligament damage. The fact that work places, schools and other institutions were rarefied or completely closed according to pandemic conditions during the process has caused individuals to spend their lives at home and do all their jobs in front of the computer (Kehribar \& Karapinar, 2019; Tural, 2020; Kayaalp et al., 2020).

With the recommendation of Scientific Committee on the cases seen in Turkey, it was decided to take some measures to decrease the spread of Covid-19 in Turkey on March 13, 2020. With the recommendations of Scientific Committee, these measures have been implemented as precautionary strategies with some principles during the process of struggling with the pandemic in Turkey (Turan \& Çelikyay, 2020). Therefore, the fact that tasks which required more activity in the pre-pandemic period were completed in 
front of the screen in an inactive manner led to the restriction of physical activity. When unhealthy nutrition was added to the lack of physical exercise, a very dangerous situation for human health emerged. It was found that during the Covid-19 pandemic, people in home quarantine had low physical activity and this affected health-related quality of life, physical function, pain and general health perception (Tural, 2020).

Global Covid-10 pandemic resulted in the closure of gyms, stadiums, pools, fitness rooms, physiotherapy centres, parks and game areas. Therefore, many individuals could not participate actively in regular individual or group sports or physical activities outside their homes. Under these conditions, most of the individuals tend to be less active physically; they have longer screen time, irregular sleep pattern and worse diet programs, which lead to loss of physical well-being in addition to weight gain.

During the pandemic, there has been an increase in the consumption of foods with high refined carbohydrate, sugar and fat content due to reasons such as individuals' mental state, increased stress and decreased physical activity (Çulfa et al., 2021). This type of diet, also called Western diet worldwide, increases the risk of developing type 2 diabetes and obesity and the individuals in this population constitute high risk group in terms of serious complications and mortality caused by Covid-19 (Dietz et al., 2020). Not having access to exercise and physical activity may cause mental health problems and this may increase the stress or anxiety many people will experience in the face of being isolated. Possible loss of family members of friends due to virus and the effects of the virus on individuals' economic welfare and access to food will exacerbate these effects.

It may still be possible for many people to exercise without any equipment and limited space. Home life may be an option to be more active during the day for those who have to sit for long hours, such as stretching, doing housework, climbing ladders or dancing to the music. Physical activity and relaxing techniques inside the house will help to stay calm and protect health during this time. World Health Organization (WHO) recommends 150 minutes of moderate or 75 minutes of vigorous physical activity a week, or a combination of both (WHO, 2020). The increase in the time spent home, watching or listening to pandemic news all the time, increased worries, increase in the desire to consume food (especially carbohydrate food) depending on the mood and decreased physical activity may cause undesired weight gain. For those who have internet access, there are many free sources on how to be active during the pandemic. For example, physical fitness games can appeal to people of all ages and they can be used in small spaces. Another important aspect of keeping physical fitness is strength training, which does not require large areas but helps to protect muscle strength; this is important especially for old people or for people with physical disability (Eskici, 2020). In addition, physical performance parameters such as strength, speed, endurance, power and agility may be affected from body composition (such as muscle mass, body fat percentage) (Bostanci et al., 2019; Ari ve Deliceoglu, 2020). Therefore, deterioration in body composition is related to sedentary life.

The closure of schools and sports fields in our country due to the pandemic, the fact that games were not played in the infrastructure and interruption of sports in schools 
caused serious movement restrictions. Cancellation or postponement of all sports activities including all lower and upper leagues can be given as examples of numerous effects of Covid-19 on sports activities (Türkmen \& Özsar1, 2020). Distance education process and the fact that this process was spent in front of the computer was another factor that caused limited physical activity. It is very important to take special measures, especially for the rehabilitation of children, while programming return to normal life after the pandemic. This group, which is the group most affected by the society, should be included in the academic planning of activity programs more than the pre-pandemic period in accordance with purposes.

\section{Material and Method}

\subsection{Participants and Procedure}

In our study, international physical activity form was applied to 278 students between the ages of 7 and 16. Physical activity levels of the students in the past week and what activities they did were determined. 162 of the participants were male, while 116 were female. 28 primary education students, 154 secondary education students and 96 high school students participated in the study. Of the students who participated in the study, while 7 had an obstacle for doing sports, it was found that 271 students did not have any obstacles. Cronbach alpha internal consistency coefficient was found as 0.89 in this study. In this descriptive study, the simple random sampling method was used.

\subsection{Data Collection Tool}

International Physical Activity Questionnaire (IPAQ) was used to find out the physical activity levels of the participants (Craig et al., 2003). Validity and reliability study of the Questionnaire was conducted by Öztürk in 2005 in Turkey (Öztürk, 2005). In our study, the 7-item self-administered short form of the Questionnaire which covers the last 1 week to evaluate the level of physical activity was used.

\subsection{Statistical Analyzes}

The SPSS version 22.0 (SPSS Inc., Chicago, IL) program was used for statistical analyzes. The data were expressed as frequency and percentage.

\section{Results}

Out study was conducted on primary school, secondary school and high school (9th and 10th grade) students. 28 participants (10.1\%) were aged between 7 and 10, 153 participants (55\%) were aged between 11 and 13 and 97 participants (34.9\%) were aged between 14 and 16. The majority of the participants were students between the ages of 11 and 13. 
Table 1: Age Ranges

\begin{tabular}{|l|c|c|}
\hline & Frequency & Percentage \\
\hline $14-16$ & 97 & 34.9 \\
\hline $11-13$ & 153 & 55.0 \\
\hline $7-10$ & 28 & 10.1 \\
\hline Total & 278 & 100.0 \\
\hline
\end{tabular}

$162(58.3 \%)$ of the 278 students who participated in the study were male, while 116 $(41.7 \%)$ were female.

Table 2: Gender

\begin{tabular}{|l|c|c|}
\hline & Frequency & Percentage \\
\hline Male & 162 & 58.3 \\
\hline Female & 116 & 41.7 \\
\hline Total & 278 & 100.0 \\
\hline
\end{tabular}

$10.1 \%$ of the participants were primary school students, $55.4 \%$ were secondary school students and $34.5 \%$ were high school students.

Table 3: Educational Status

\begin{tabular}{|l|c|c|}
\hline & Frequency & Percentage \\
\hline Primary & 28 & 10.1 \\
\hline Secondary & 154 & 55.4 \\
\hline High school & 96 & 34.5 \\
\hline Total & 278 & 100.0 \\
\hline
\end{tabular}

While $97.5 \%$ of the students stated that they did not have an obstacle to doing sports, $2.5 \%$ stated that they had an obstacle to doing sports.

Table 4: The state of having an obstacle to doing sports

\begin{tabular}{|l|c|c|}
\hline & Frequency & Percentage \\
\hline Yes & 7 & 2.5 \\
\hline No & 271 & 97.5 \\
\hline Total & 278 & 100.0 \\
\hline
\end{tabular}

Our study aimed to find out the frequency of activities performed in the last 7 days. The participants were asked to indicate the level of physical activity they did for all days of the week separately. When the results are reviewed, it can be seen that they generally intensified on the option "sometimes" for all days of the week. 


Monday
\begin{tabular}{|l|c|c|}
\hline & Frequency & Percentage \\
\hline Never & 47 & 16.9 \\
\hline Rarely & 39 & 14.0 \\
\hline Sometimes & 105 & 37.8 \\
\hline Mostly & 67 & 24.1 \\
\hline Always & 20 & 7.2 \\
\hline Total & 278 & 100.0 \\
\hline
\end{tabular}

\section{Tuesday}

\begin{tabular}{|l|c|c|}
\hline & Frequency & Percentage \\
\hline Never & 43 & 15.5 \\
\hline Rarely & 58 & 20.9 \\
\hline Sometimes & 89 & 32.0 \\
\hline Mostly & 70 & 25.2 \\
\hline Always & 18 & 6.5 \\
\hline Total & 278 & 100.0 \\
\hline
\end{tabular}

\section{Wednesday}

\begin{tabular}{|l|c|c|}
\hline & Frequency & Percentage \\
\hline Never & 44 & 15.8 \\
\hline Rarely & 59 & 21.2 \\
\hline Sometimes & 84 & 30.2 \\
\hline Mostly & 67 & 24.1 \\
\hline Always & 24 & 8.6 \\
\hline Total & 278 & 100.0 \\
\hline
\end{tabular}

\section{Thursday}

\begin{tabular}{|l|c|c|}
\hline & Frequency & Percentage \\
\hline Never & 46 & 16.5 \\
\hline Rarely & 54 & 19.4 \\
\hline Sometimes & 85 & 30.6 \\
\hline Mostly & 72 & 25.9 \\
\hline Always & 21 & 7.6 \\
\hline Total & 278 & 100.0 \\
\hline
\end{tabular}

Friday

\begin{tabular}{|l|c|c|}
\hline & Frequency & Percentage \\
\hline Never & 45 & 16.2 \\
\hline Rarely & 57 & 20.5 \\
\hline Sometimes & 80 & 28.8 \\
\hline Mostly & 65 & 23.4 \\
\hline Always & 31 & 11.2 \\
\hline Total & 278 & 100.0 \\
\hline
\end{tabular}




\section{Saturday}

\begin{tabular}{|l|c|c|}
\hline \multicolumn{1}{|c|}{} & Frequency & Percentage \\
\hline Never & 59 & 21.2 \\
\hline Rarely & 50 & 18.0 \\
\hline Sometimes & 78 & 28.1 \\
\hline Mostly & 64 & 23.0 \\
\hline Always & 27 & 9.7 \\
\hline Total & 278 & 100.0 \\
\hline
\end{tabular}

\section{Sunday}

\begin{tabular}{|l|c|c|}
\hline & Frequency & Percentage \\
\hline Never & 58 & 20.9 \\
\hline Rarely & 55 & 19.8 \\
\hline Sometimes & 77 & 27.7 \\
\hline Mostly & 58 & 20.9 \\
\hline Always & 30 & 10.8 \\
\hline Total & 278 & 100.0 \\
\hline
\end{tabular}

When the answers were examined to the question of how and in which environment physical activities were performed, the following answers were found:

\subsection{Exercise in gyms (fitness, step, aerobic etc.)}

\begin{tabular}{|l|c|c|}
\hline & Frequency & Percentage \\
\hline Not at all & 175 & 62.9 \\
\hline $1-2$ times & 33 & 11.9 \\
\hline 3-4 times & 38 & 13.7 \\
\hline 5-6 times & 18 & 6.5 \\
\hline 7 times and more & 14 & 5 \\
\hline Total & 278 & 100 \\
\hline
\end{tabular}

\subsection{Exercise at home (step, aerobic, etc.)}

\begin{tabular}{|l|c|c|}
\hline & Frequency & Percentage \\
\hline Not at all & 67 & 24.1 \\
\hline $1-2$ times & 45 & 16.2 \\
\hline 3-4 times & 63 & 22.7 \\
\hline 5-6 times & 48 & 17.3 \\
\hline 7 times and more & 55 & 19.8 \\
\hline Total & 278 & 100 \\
\hline
\end{tabular}




\subsection{Playing games jumping games such as hopscotch/jumping rope}

\begin{tabular}{|l|c|c|}
\hline & Frequency & Percentage \\
\hline Not at all & 112 & 40.3 \\
\hline 1-2 times & 49 & 17.6 \\
\hline 3-4 times & 48 & 17.3 \\
\hline 5-6 times & 37 & 13.3 \\
\hline 7 times and more & 32 & 11.5 \\
\hline Total & 278 & 100 \\
\hline
\end{tabular}

\subsection{Playing moving games such as tag and dodgeball}

\begin{tabular}{|l|c|c|}
\hline & Frequency & Percentage \\
\hline Not at all & 119 & 42.8 \\
\hline 1-2 times & 45 & 16.2 \\
\hline 3-4 times & 46 & 16.5 \\
\hline 5-6 times & 20 & 7.2 \\
\hline 7 times and more & 48 & 17.3 \\
\hline Total & 278 & 100 \\
\hline
\end{tabular}

\subsection{Playing chasing games}

\begin{tabular}{|l|c|c|}
\hline & Frequency & Percentage \\
\hline Not at all & 114 & 41 \\
\hline $1-2$ times & 39 & 14 \\
\hline 3-4 times & 43 & 15.5 \\
\hline $5-6$ times & 26 & 9.4 \\
\hline 7 times and more & 56 & 20.1 \\
\hline Total & 278 & 100 \\
\hline
\end{tabular}

\subsection{Walking for exercise}

\begin{tabular}{|l|c|c|}
\hline & Frequency & Percentage \\
\hline Not at all & 50 & 18 \\
\hline 1-2 times & 45 & 16.2 \\
\hline 3-4 times & 69 & 24.8 \\
\hline 5-6 times & 46 & 16.5 \\
\hline 7 times and more & 68 & 24.5 \\
\hline Total & 278 & 100 \\
\hline
\end{tabular}




\subsection{Riding bike}

\begin{tabular}{|l|c|c|}
\hline & Frequency & Percentage \\
\hline Not at all & 86 & 30.9 \\
\hline 1-2 times & 28 & 10.1 \\
\hline 3-4 times & 29 & 10.4 \\
\hline 5-6 times & 42 & 15.1 \\
\hline 7 times and more & 93 & 33.5 \\
\hline Total & 278 & 100 \\
\hline
\end{tabular}

\subsection{Running}

\begin{tabular}{|l|c|c|}
\hline & Frequency & Percentage \\
\hline Not at all & 48 & 17.3 \\
\hline 1-2 times & 43 & 15.5 \\
\hline 3-4 times & 44 & 15.8 \\
\hline 5-6 times & 54 & 19.4 \\
\hline 7 times and more & 89 & 32 \\
\hline Total & 278 & 100 \\
\hline
\end{tabular}

\subsection{Dancing}

\begin{tabular}{|l|c|c|}
\hline & Frequency & Percentage \\
\hline Not at all & 140 & 50.4 \\
\hline 1-2 times & 43 & 15.5 \\
\hline 3-4 times & 25 & 9 \\
\hline 5-6 times & 25 & 9 \\
\hline 7 times and more & 45 & 16.2 \\
\hline Total & 278 & 100 \\
\hline
\end{tabular}

\subsection{Playing football}

\begin{tabular}{|l|c|c|}
\hline & Frequency & Percentage \\
\hline Not at all & 133 & 47.8 \\
\hline 1-2 times & 32 & 11.5 \\
\hline 3-4 times & 30 & 10.8 \\
\hline 5-6 times & 21 & 7.6 \\
\hline 7 times and more & 62 & 22.3 \\
\hline Total & 278 & 100 \\
\hline
\end{tabular}




\subsection{Skate boarding}

\begin{tabular}{|l|c|c|}
\hline & Frequency & Percentage \\
\hline Not at all & 229 & 82.4 \\
\hline 1-2 times & 17 & 6.1 \\
\hline 3-4 times & 10 & 3.6 \\
\hline 5-6 times & 6 & 2.2 \\
\hline 7 times and more & 16 & 5.8 \\
\hline Total & 278 & 100 \\
\hline
\end{tabular}

\subsection{Playing volleyball}

\begin{tabular}{|l|c|c|}
\hline & Frequency & Percentage \\
\hline Not at all & 144 & 51.8 \\
\hline 1-2 times & 51 & 18.3 \\
\hline 3-4 times & 31 & 11.2 \\
\hline 5-6 times & 29 & 10.4 \\
\hline 7 times and more & 23 & 8.3 \\
\hline Total & 278 & 100 \\
\hline
\end{tabular}

\subsection{Playing basketball}

\begin{tabular}{|l|c|c|}
\hline & Frequency & Percentage \\
\hline Not at all & 116 & 41.7 \\
\hline $1-2$ times & 39 & 14 \\
\hline 3-4 times & 39 & 14 \\
\hline 5-6 times & 26 & 9.4 \\
\hline 7 times and more & 58 & 20.9 \\
\hline Total & 278 & 100 \\
\hline
\end{tabular}

\subsection{Doing gymnastics}

\begin{tabular}{|l|c|c|}
\hline & Frequency & Percentage \\
\hline Not at all & 170 & 61.2 \\
\hline 1-2 times & 48 & 17.3 \\
\hline 3-4 times & 25 & 9 \\
\hline 5-6 times & 17 & 6.1 \\
\hline 7 times and more & 18 & 6.5 \\
\hline Total & 278 & 100 \\
\hline
\end{tabular}




\subsection{Walking/playing with a pet}

\begin{tabular}{|l|c|c|}
\hline & Frequency & Percentage \\
\hline Not at all & 180 & 64.7 \\
\hline 1-2 times & 22 & 7.9 \\
\hline 3-4 times & 18 & 6.5 \\
\hline 5-6 times & 17 & 6.1 \\
\hline 7 times and more & 41 & 14.7 \\
\hline Total & 278 & 100 \\
\hline
\end{tabular}

\section{Discussion and Conclusion}

Since the day Covid-19 virus entered our lives, there have been radical changes in our daily routines. We are now living in an environment in which we cannot do many activities we have done before the pandemic. With restrictions, people had to adopt a lifestyle they had to fit into limited spaces and times in their homes. This unfamiliar situation led to changes in physical activity and dietary styles. Especially the fact that students had to continue education online in front of a computer and that their lives evolved into a stagnation from an extremely active life style of going to school five days a week and participating in sport activities with friends has caused great problems. This immobile lifestyle brought with it irregular eating, sleeping and physical activity patterns. Especially the fact that people were not informed sufficiently at the beginning of the process and they were not warned that the problems that may occur after the pandemic may harm as much as contacting with the virus caused the process to continue unhealthily.

The aim of our study was to research the physical activity states of children between the ages of 7 and 16 during the pandemic process. A total of 278 students, 162 males and 116 females, between the ages of 7 and 16 participated in the study. The age groups were determined as 7 and 10 years of age primary education students, 11 and 13 years of age secondary education students, and 14 and 16 years of age 9th and 10th graders. 55\% of the participants were between 11 and 13 years of age, $34.9 \%$ were between 14 and 16 years of age and $10.1 \%$ between 7 and 10 years of age.

While $97.5 \%$ of the students stated that they did not have an obstacle to doing sports, $2.5 \%$ stated that they had an obstacle to doing sports. As a result of the analysis about the frequency of physical activity, it was found that the group the study was conducted on was moderately active. The rate of those highly active was $8.8 \%$, the rate of those very active was $23.8 \%$, the rate of those moderately active was $30.74 \%$, the rate of those slightly active was $19.11 \%$ and the rate of inactive (sedentary) students was found as $17.57 \%$. According to the results of the physical activity Questionnaire applied on a similar group of students before the pandemic, it was found that $14.12 \%$ of the students were inactive (sedentary), 38.93\% were active in a low level, 36.26\% were moderately active, $8.45 \%$ were very active and $2.39 \%$ were highly active (Konca, E. et al., 2019). When the pandemic period was compared with pre-pandemic period, it was found that the 
number of inactive individuals increased, while the rate of individuals who were active in a low level decreased. When the pandemic and pre-pandemic period physical activity levels are examined in general, it can be seen that the rate of moderately active individuals was similar in both periods. It can be seen that the rate of those who were highly active was higher in the pandemic period when compared with the pre-pandemic period. It can be said that the level of activity in the pandemic period was higher when compared with the pre-pandemic period. When the distribution of level of activity in the last week was examined in terms of days, it was concluded that the participants were moderately active with a rate of $30.74 \%$ and highly active with a rate of $23.8 \%$ in all days of the week.

When the types of activities done were examined, it was found that the rate of activities done at home increased when compared with the activities done at gym. The rate of those who stated that they never did sports at gym was $62.9 \%$. While $40.3 \%$ did not play games that require explosive power such as jumping rope and hopscotch, the other options were close to each other. While $42.8 \%$ of the participants stated that they did not do any activities such as tag and dodgeball, the rate of the participants who stated that they did these activities 7 times and more was $17.3 \%$. While $41 \%$ did not do aerobic activities such as chasing at all, 20.1\% did these activities 7 times and more. It was concluded that activities done for healthy life and exercise were done more than other activities. $24.5 \%$ of the participants stated that they did this kind of activity 7 times and more, while $24.8 \%$ stated that they did this kind of activity 3-4 times a week. While $33.5 \%$ stated that they rode bike 7 times and more, $30.9 \%$ stated that they did not ride bike at all. While $32 \%$ stated that they ran 7 or more times, $19.4 \%$ stated that they ran 5-6 times. While the rate of those who stated that they did not do any activities with rhythm such as dancing was $50.4 \%$, the rate of those who did these activities 7 times and more was $16.2 \%$. Football, which is normally one of the most common activities, was one of the most difficult activities to perform during the pandemic. While $47.8 \%$ of the participants stated that they didn't play football at all, $22.3 \%$ stated that they played 7 times or more. $82.4 \%$ of the students, in other words a great majority, stated that they did not do the activity of skateboarding at all, which is a difficult activity to perform under pandemic conditions. While $51.8 \%$ of the participants stated that they didn't play volleyball at all, $18.3 \%$ stated that they played 1-2 times. $41.7 \%$ of the participants stated that they didn't play basketball at all, while $20.9 \%$ stated that they played 7 times or more. $61.2 \%$ of the participants stated that they did not do any gymnastics, $17.3 \%$ stated that they did 1-2 times. While $64.7 \%$ stated that they did not walk or play with a pet at all, $14.7 \%$ stated that they did this activity 7 times and more. When the types of doing activity are considered in general, it can be seen that during the pandemic, the activities which are easy to perform at home and school and also less risky are preferred more. It can be seen that individuals generally stayed away from team sports. Activities which are easy to do but at the same time less risky, such as running and walking for exercise, have been activities which have come to the forefront during the pandemic. 


\title{
Conflict of Interest Statement
}

The authors declare no conflicts of interests.

\begin{abstract}
About the Authors
Erkan Konca has a Master of Science degree in the sport science field.

Dr. Egemen Ermiş is Associate Professor Doctor at Ondokuz Mayıs University, Yaşar Doğu Faculty of Sports Sciences, Samsun, Turkey.

Dr. Necati Alp Erilli is Associate Professor Doctor at Sivas Cumhuriyet University, Faculty of Economics Department of Econometrics, Statistical Department, Sivas, Turkey.
\end{abstract}

\section{References}

Acar, K., \& Y1lmaz, A. K. (2020). The Effect of Isolation on Social Physique Anxiety and Fat Phobia in Athletes During the Covid-19 Pandemic. Pakistan Journal of Medical \& Health Sciences, 15(2), 883-888.

Ari E., Deliceoglu G. (2020). The examination of some anthropometric and motoric characteristics of students aged eight years according to their maturation level. Baltic Journal of Health and Physical Activity, 12(2): 45-63.

Booth F. W., Roberts C. K., Laye M. J. (2012). Lack of Exercise is a majör cause of chronic diseases. Compr Physiol, 2(2):1143-1211.

Bostanc1, Ö., Kabadayı, M., Mayda, M. H., Yilmaz, A. K., \& Y1lmaz, C. (2019). The differential impact of several types of sports on pulmonary functions and respiratory muscle strength in boys aged 8-12. Isokinetics and Exercise Science, 27(4), 307-312.

Craig C. L., Marshall A. L., Sjöström M., Bauman A. E., Booth M. L., Ainsworth B. E. (2003). International physical activity questionnaire: 12-country reliability and validity. Med Sci Sports Exerc, 35(8):1381-1395.

Çulfa, S., Yıldırım, E., \& Bayram, B. (2021). The Relationship between Obesity and Changing Nutrition Habits in Human during COVID-19 Pandemic, Online Turkish Journal of Health Sciences, 6(1):135-142.

Dietz W., Santos-Burgoa C. (2020). Obesity and its implications for COVID-19 mortality. Obesity (Silver Spring), 28(6):1005.

Eskici G. (2021). Covid-19 quarantine: Recommendations for nutrition, weight control and immunity agenda: nutrition recommendations for ramadan in quarantine. Çanakkale Onsekiz Mart University, Faculty of Sport Sciences.

https://cdn.comu.edu.tr/cms/sporbf/files/1505-karantinada-ramazan-ayibeslenme-onerileri.pdf.

Jiménez-Pavón D., Carbonell-Baeza A., Lavie C. J. (2020). Physical exercise as therapy to fight against the mental and physical consequences of COVID-19 quarantine: Special focus in older people. Prog Cardiovasc Dis, 63(3): 386-388. 
Kayaalp, M. E., Korkmaz, Ö., Kehribar, L., \& Mahiroğulları, M. Primary anterior cruciate ligament repair. Turkish Orthopedics and Traumatology Association Journal, 19, 523-533.

Kehribar, L., \& Karapinar, L. (2019). Comparison of surgical treatment results and clinical and radiological findings of tibial plateau fractures. SANAMED, 14(2), 147-152.

Konca, E., Ermiş, E., Ermiş, A., Erilli, N.A. (2019). Investigation of physical activity status and nutritional habits of 7-14 year old students. Turkish Studies Social Science, 14(1), 105-117.

Mayda, M. H., Erail, S., \& Karaduman, E. (2020). Examination of self-regulated online learning skills in faculty of sports sciences students. European Journal of Education Studies, 7(11), 767-775.

Özdal, M. (2020). Respiratory muscle exercises may be effective at reducing the symptoms of COVID-19. EC Pulmonology and Respiratory Medicine, 9(6), 45-49.

Öztürk M. (2005). The validity and reliability of the international physical activity questionnaire and determination of physical activity levels in university education students. Master Thesis. Hacettepe University Institute of Health Sciences.

Tural, E. (2020). The effect of physical activity level on quality of life in covid-19 pandemic period home quarantine. Van Sag Bil Derg, 13 (Special Issue):10-18

Turan, A., Çelikyay, H. (2020). Combating COVID-19 in Turkey: Policies and actors. Journal of the International Academy of Management, 3(1), 1-25.

Türkmen, M. \& Özsarı, A. (2020). Covid-19 outbreak and its effects on sports industry. International Journal of Sport Culture and Science, 8(2), 55-67.

WHO. (2020). Considerations for quarantine of individuals in the context of containment for coronavirus disease (COVID-19) Interim guidance 19 March 2020. https://apps.who.int/iris/handle/10665/331497. 
Erkan Konca, Egemen Ermiş, Necati Alp Erilli

ANALYSIS OF PHYSICAL ACTIVITY STATES OF STUDENTS

BETWEEN 7-16 AGE GROUP DURING COVID-19 PROCESS

Creative Commons licensing terms

Authors will retain the copyright of their published articles agreeing that a Creative Commons Attribution 4.0 International License (CC BY 4.0) terms will be applied to their work. Under the terms of this license, no permission is required from the author(s) or publisher for members of the community to copy, distribute, transmit or adapt the article content, providing a proper, prominent and unambiguous attribution to the authors in a manner that makes clear that the materials are being reused under permission of a Creative Commons License. Views, opinions and conclusions expressed in this research article are views, opinions and conclusions of the author(s). Open Access Publishing Group and European Journal of Physical Education and Sport Science shall not be responsible or answerable for any loss, damage or liability caused in relation to/arising out of conflict of interests, copyright violations and inappropriate or inaccurate use of any kind content related or integrated on the research work. All the published works are meeting the Open Access Publishing requirements and can be freely accessed, shared, modified, distributed and used in educational, commercial and non-commercial purposes under a Creative Commons attribution 4.0 International License (CC BY 4.0). 